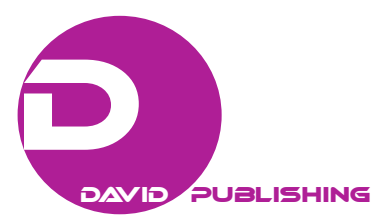

\title{
Impact of Human Resource Management on Economy: Firm Management Perspective
}

\author{
Gürhan Uysal \\ Ondokuz Mayıs University, Samsun, Turkey
}

\begin{abstract}
Firms produce national GDP in an economy. There are several functions in firm management, and managers operate those functions. They are logistics, supply, stock, finance, accounting, marketing, production, etc. All have managers such as accounting manager, finance manager, marketing manager, etc. Performance of managers is crucial to firm performance. Because performance of managers might become one determinator of firm performance. Therefore, HRM may have an impact on GDP through managers. Because productions and sales of firms affect GDPs in an economy.
\end{abstract}

Keywords: GDP, professionals, managers, HRM, firm performance

\section{Introduction}

HR is related with performance and talent management. HR aims to increase individual performance, and it aims to have an impact on firm performance through employee performance. Talent Management is to appoint talented candidates for management positions. Assumed that talented person (managers) may have an impact on firm performance. Because in the article of 1992 in Journal of Management, Wright and McMahan said that HRM aims to have an impact on firm performance. Furthermore, next phase of capitalism may be human resources. Because Human Resources is intellectual capital and human capital of company, and human capital may create firm performance for firm. Peter Drucker (2015) symbolized that with knowledge workers.

Scholars argue 4th Industrial Revolution and human resource management relation. Human Capital approach may establish relationship between 4th Industrial Revolution and Human resource management. Because factory system exists in Industrial Revolution in 1800s. And there are machines and workers in a factory. Therefore, human capital (or machine-worker relationship) may establish relation between HRM and 4th IR. Because there are technologies in factories, and personnel runs the technology in firms. Karl Marx (2007) mentions for labor value in firms; however, technology-value may affect organizations today.

\section{Impact of HRM on Economy: Through Managers}

Talent Management may be applied to economy management with figure that is described as appointment of executives into management positions. Firms have some business departmants. They are, for example, finance department, logistics department, manufacturing department, marketing, and others. They need managers to effectively manage the department. Because those departments generate organizational performance. It is (talent management) important because performance of managers has an impact on

Gürhan Uysal, associate professor/Ph.D., School of Business, Ondokuz Mayis University, Samsun, Turkey.

Correspondence concerning this article should be addressed to Gürhan Uysal, School of Business, Ondokuz Mayıs University, Kurupelit Campus, 3rd floor, 55139, Samsun, Turkey. 
performance of business departments, and all departments' performance comes together, and makes up the firm performance such as market share, sales, profit, and amount of production. Talent management is identified with appointing ability managers to management positions in firms.

GDP may be defined with quantity of production, or total of firm's sales. It is expected that managers and professionals increase total sales, profit, and amount and quality of production. Thus, managers may have an impact on national GDP through market sales and production.

\section{Case Study: Ford and GM}

According to Drucker (2009), managers may have an impact on firm performance. General Motors and Ford Motor Company have economic difficulty during 1920s. Alfred Sloan became CEO of GM in 1922. GM was established by small automobile companies, such as Buick, Oldsmobile, and Chevrolet. And ex-owners continue managing those companies. Sloan changed the management in those companies operating under GM structure and he appointed professionals to management positions instead of ex-owners. And GM becomes 1st rank in automobile industry. Furthermore, Henry Ford II became CEO of FMC in 1946. Soon, he changed ex-management at the top of Ford Company. Because ex-managers became outmoded and Ford Company obtained organizational success in automobile industry by new managers.

\section{HRM and Quantitative Methods}

Venn diagrams may describe inside relations between Human Resource methods. Venn symbolized sets and subsets of mathematics. And that might figure relationship between HR methodologies.

There are three human resource methodologies: Personnel Management, Human Resource Management, and Strategic Human Resource Management. Each has historical chronology. But none of them is forgetten by businesses because each of them must be applied together. So, Venn figured this necessary below.

Personnel Management is associated with "job performance". PM is oriented to increase job performance at firms. HRM is oriented to "employee performance". HRM aims to increase performance of employees through HRM practices. Strategic HRM focuses on "firm performance". Both focus of PM, and HRM are to increase firm performance. Therefore, firms apply three HR methods together in firms.

So, Venn diagrams of HR methods are:

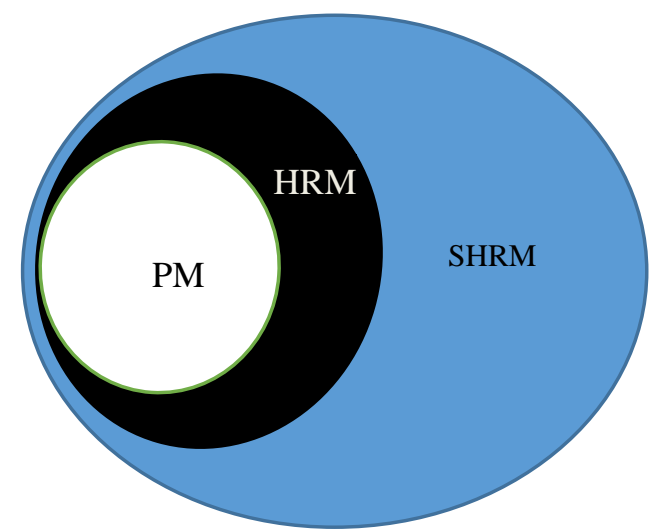

Figure 1. Venn relations of HR methods, PM, HRM, Strategic HRM.

Accordingly, white curve is PM; black curve is HRM; and the other is written as strategic HRM. Those are the sets and subsets of human resource management. 


\section{Set Theorem and Establishing HRM Department Through HR System}

Major limit of top management in firm management might be "budget limit”. Managers are restricted with budget constraints, especially in investment. That might be the case for human resource management. Human resource management in firms may be limited by budget constraints. For example, it is for training. Number of trainees may be determined by budget limit, or compensation or wage is determined by total budget. HR planning, the most prominent HR practice, is limited by personnel budget allocation of firm management. Therefore, mathematic of limit may be applied to human resource management. For example, managers' viewpoint against HRM determines strength of HRM in organization. So, managers' point of view of HRM is maybe another limit that restricts human resource application in firms.

Secondly, core application of SHRM in firms might be HR system and HR system may be established in organizations through set theorem. System theory figures that subsystems establish system in firms. There are some HRM practices that applied in firms. They are HR planning, staffing, recruitment, compensation, career planning, performance appraisal, training, etc. Those practices may establish subsystem (set) in HR system. And they come together (subsystems), and make up HR system in organization. This is set theorem of mathematic that may be used in human resource management. Because firms may establish HR department in their organizations through set and HR system notion.

\section{Professionals and Theory: Task Performance}

New paradigm of HRM might be task performance. Because organizations consist of tasks and professionals implement those tasks in organizations. Therefore, their individual performance at task is important to firm management.

New paradigm of HRM might become "task performance". Because tasks may increase organizational performance in firms. And professionals implement tasks in organizations. Therefore, their individual performance in task must become important to HRM department. This study supposes that theoretical knowledge of employees increases task performance of employees. Further, competence of employees increases task performance of employees. For competent, employees (professionals) must have theoretical knowledge in his/her business field. For example, HR professionals must have HRM-related theoretical knowledge to effectively implement its task in HRM department. On this matter, SHRM carries certification programs and annual conferences for employee competence. Objective of HRM is to have impact on organizational performance (Wright \& McMahan, 1992). It is assumed that if professionals are competent, organizational performance increases through task performance.

\section{Case Study: Peter Drucker and Effective Management}

Case study approach would be used in this study. Peter Drucker mentioned for technolog in his book, Management Frontiers. According to Peter Drucker, professionals or workers must become technological. It contains both theory and practice. For example, telephone maintenance expert in Bell Atlantic Company must become technological to achieve customer's satisfaction. Expert must have theoretical knowledge in telephone industry, and must have job experience in telephone maintenance. Similar conditions must exist for firm's professionals. For example, a marketing manager of company possesses theory in marketing and it has practical experience in marketing field.

Peter Drucker is management consultant and academic person. He searched for effective management during his career. He presumed that theoretical knowledge may make a manager effective in his/her career. 
Therefore, it may become responsibility of HRM departments in firms to gain theoretical knowledge for professionals. For example, training division may organize theoretical training program for marketing professionals in marketing field. Or HR department may enroll professionals for PhD. and MBA. Programs, who have career planning and career maps in organizations. This theoretical knowledge may increase task performance of employees. For example, professionals may apply product life cycle, GE matrix, and Hofer analysis in his/her career after theoretical training.

\section{Conclusion}

To conclude, professionals must have theoretical knowledge in his/her career field. Theoretical knowledge may increase task performance of employees and organizational performance, consequently, because organizations consist of tasks and professionals.

Further, according to assumption of this study, managers may have an impact on national GDP through firm performance. Therefore, talent management gains importance for top management in firm, because firm performance (production, sales) has an impact on GDP in an economy.

\section{References}

Drucker, P. (2009). Management. Istanbul: Optimist Publishing.

Drucker, P. (2015). Frontiers of management. Istanbul: Optimist.

Von Mises, L. (2007). Socialism. Ankara: Liberte Publishing.

Wright, P. M., \& McMahan, G. C. (1992). Theoretical perspectives for strategic human resource management. Journal of Management, 18(2), 295-320. 